\title{
Sustained Release of IGF-1 by 3D Mesoporous Scaffolds Promoting Cardiac Stem Cell Migration and Proliferation
}

\author{
Yuning Sun ${ }^{\mathrm{a}}$ Xiqiong Han ${ }^{\mathrm{a}}$ Xin Wang ${ }^{\mathrm{a}}$ Boqian Zhu ${ }^{\mathrm{a}}$ Bing $\mathrm{Li}^{\mathrm{a}}$ \\ Zhongpu Chen ${ }^{\mathrm{a}}$ Genshan Ma ${ }^{\mathrm{a}}$ Mimi Wan $^{\mathrm{b}}$ \\ aDepartment of Cardiology, Zhongda Hospital, Medical School of Southeast University, Nanjing, \\ ${ }^{b}$ National and Local Joint Engineering Research Center of Biomedical Functional Materials, School of \\ Chemistry and Materials Science, Nanjing Normal University, Nanjing, China
}

\section{Key Words}

Drug release $\cdot$ IGF-1 $\bullet$ 3D mesoporous scaffolds $\cdot$ Cardiac stem cells

\begin{abstract}
Background/Aims: C-kit-positive cardiac stem cells (CSCs) may have potential as a treatment for cardiovascular disease. However, the low survival rates of c-kit-positive CSCs present a major challenge during the transplantation process. Methods: The hierarchical structure of the $3 \mathrm{D}$ cell scaffold was characterized by scanning electron microscopy (SEM), transmission electron microscopy (TEM), X-ray diffraction (XRD), and $\mathrm{N}_{2}$ adsorption-desorption isotherms. Analyses of the proliferation and migration performances of the IGF-1 scaffold on c-kitpositive CSCs were conducted by experiments including QuantiT PicoGreen dsDNA and transwell assays. Results: In this study, we synthesized for the first time a novel hierarchical macro-mesoporous silica material (denoted MS15-c) in a one-pot procedure for the release of insulin-like growth factor-1 (IGF-1) and a three-dimensional (3D) cell scaffold. Both macropores and mesopores were visible in MS15-c and enabled the sustained release of IGF-1, extending its half-life and enhancing CSC proliferation and migration. Proliferation and migration were detected by QuantiT PicoGreen dsDNA and transwell assays, respectively. Moreover, an in vivo experiment was conducted to detect heart function with the addition of MS15-c. The new strategy proposed in this paper may extend the bio-applications of 3D cell scaffolds, thus permitting the sustained release of growth factors and efficient promotion of cell proliferation. Conclusion: This work successfully demonstrated an effective strategy for the construction of MS15-c cell scaffolds with hierarchical macro-mesoporous structures. The macro-mesoporous structures gave cell scaffolds the ability to release a growth factor to facilitate cell growth, while the scaffold structure promoted cell proliferation.
\end{abstract}




\section{Cellular Physiology Cell Physiol Biochem 2018;49:2358-2370 \\ and Biochemistry \begin{tabular}{l|l} 
DOI: 10.1159/000493836 & $\begin{array}{l}\text { O 2018 The Author(s). Published by S. Karger AG, Basel } \\
\text { www.karger.com/cpb }\end{array}$
\end{tabular} \\ Sun et al.: 3D Mesoporous Scaffolds Sustained Release IGF-1}

\section{Introduction}

Cardiovascular disease (CVD) accounted for 30.8\% of all American deaths in 2013, which corresponds to more than 2, 200 Americans dying of CVD per day [1]. Therefore, CVD is an enormous health and economic burden for not only individual families but also the world. C-kit-positive resident cardiac stem cells (CSCs) can differentiate into cardiomyocytes, smooth muscle, and endothelial cells in vitro. Recent research has focused on the paracrine effects and the differentiation of c-kit-positive CSCs into smooth muscle and endothelial cells in vivo after engraftment to reverse the process of CVD [2-5]. However, the survival rate of c-kit-positive CSCs after transplantation is unsatisfactory-less than $5 \%$ of transplanted c-kit-positive CSCs survive in the mouse heart, making the CSC survival rate a key limiting factor for their application [6].

Insulin-like growth factor-1 (IGF-1) is a peptide with a molecular mass of $7.6 \mathrm{kDa}$ that is produced in the liver and secreted into the circulation [7-8]. It regulates cell survival, proliferation, differentiation, and metabolism [7], and is especially important in the circulatory system [9]. Moreover, reduced IGF-1 levels can increase the risk of developing CVDs, such as ischaemic heart disease, congestive heart failure, and acute myocardial infarction. Additionally, IGF-1 signaling promotes endogenous cardiac stem cell survival in vitro, and IGF-1 treatment improves left ventricular function and reduces the infarct size after acute myocardial infarction (AMI) in vivo [10]. However, the endogenous IGF-1 levels are too low to induce such beneficial effects; therefore, the sustained release of IGF-1 may be a promising method to increase c-kit-positive CSC migration and proliferation.

Over the past decade, numerous nanomaterials, such as liposomes [11], gold nanoparticles [12], polyplex [13], quantum dots [14], and mesoporous silica materials [15], have been applied in biomedical fields to improve the therapeutic outcomes. Recently, researchers have begun to investigate the effect of biomaterials on stem cells, thus illustrating that the use of biomaterials may offer an efficient choice for c-kit-positive CSC migration and proliferation. Among the existing biomaterials, mesoporous silica materials have drawn increasing attention as drug release carriers for a variety of biomedical applications because of their controllable surface area, pore diameter, multifunctional surface properties, and biocompatibility [16-18]. These characteristics likely make mesoporous silica materials efficient carriers for the sustained release of IGF-1 to extend the half-life [19-24].

However, the requirements for mesoporous materials are gradually increasing because of the high demands of various applications. For instance, the environment for the growth of cells involves a hierarchical system but traditionally used mesoporous silica nanoparticles cultured with cells cannot simulate a true three-dimensional (3D) environment for growth. It has recently been reported that materials with 3D structures, that is, 3D cell scaffolds, can modulate cell populations and promote the growth of cells [25-27].

Herein, a novel 3D mesoporous silica with a hierarchical structure was designed, synthesized, and used as a drug release carrier of loaded IGF-1. In addition, 3D cell scaffolds promoted CSC migration and proliferation. The macropores act as 3D scaffolds to accumulate cells, and the mesopores permit the sustained release of growth factors that can extend the half-life of IGF-1. The hierarchical structure of the 3D cell scaffold was characterized by scanning electron microscopy (SEM), transmission electron microscopy (TEM), X-ray diffraction (XRD), and $\mathrm{N}_{2}$ adsorption-desorption isotherms. The adsorption and release behavior was studied in detail, and it was found that up to $12 \mu \mathrm{g} \mathrm{g}^{-1}$ IGF-1 could be adsorbed and the sustained release can last for at least $250 \mathrm{~h}$. Analyses of the proliferation and migration performances of the IGF-1 scaffold on c-kit-positive CSCs were conducted by experiments including QuantiT PicoGreen dsDNA and transwell assays. 


\section{Materials and Methods}

\section{Materials}

Pluronic $\mathrm{P} 123\left(\mathrm{EO}_{20} \mathrm{PO}_{70} \mathrm{EO}_{20}, \mathrm{Mw}=\right.$ 5800) was obtained from Sigma (USA). Tetraethoxysilane (TEOS) was purchased from Nanjing Chemical Reagent (China). IGF-1 was purchased from R\&D USA. High glucose Dulbecco's Modied Eagle Medium (DMEM) and trypsin solution with the concentration of $0.25 \%$ were bought from Hyclone (Logan, Utah, US). Fetal bovine serum (FBS) was bought from Sangon Biotech. 6-Diamidino-2-phenylindole (DAPI) was purchased from Biosharp.

Synthesis of MS15-as and MS15-c with $3 D$ structure and hierarchical porous structure (Fig.1)

Firstly, $0.3 \mathrm{mmol}$ of $\mathrm{P} 123$ was dissolved into acetic acid solution (0.01 $\mathrm{M}, 16 \mathrm{~mL}$ ). When a clear solution was

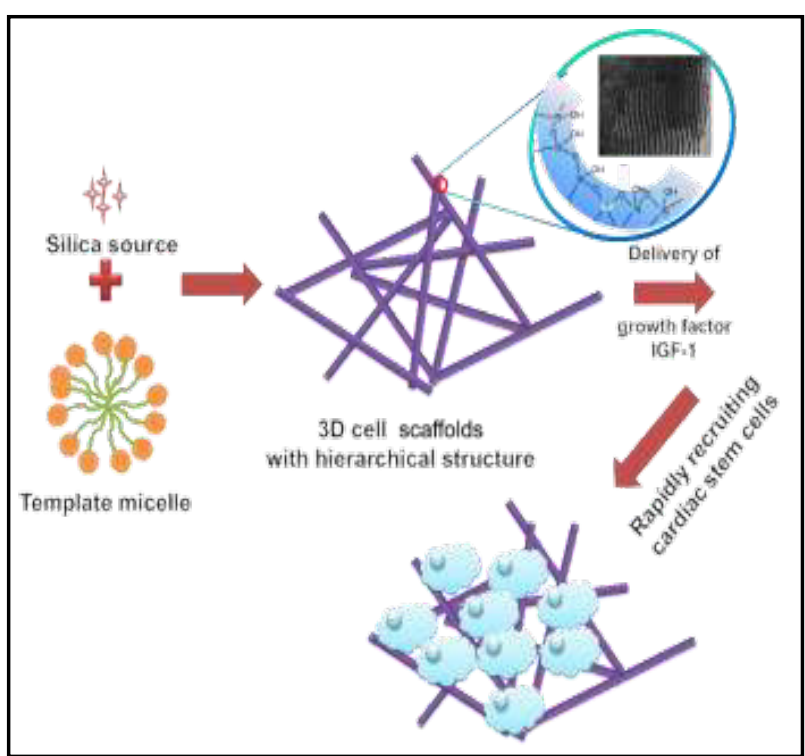

Fig. 1. Schematic illustration of the formation of $3 \mathrm{D}$ mesoporous cell scaffolds.

obtained, the solution was stirred under $0^{\circ} \mathrm{C}$ for $5 \mathrm{~min}$. Then $16.7 \mathrm{mmol}$ of urea was added, followed by the addition of $13.3 \mathrm{mmol}$ of TMOS. The obtained mixture was then transferred to an 24-well plate by aging at $60^{\circ} \mathrm{C}$ in an oven for $3 \mathrm{~d}$. The final product was washed and dried, which was denoted as MS15-as. In order to get MS15-c sample, the obtained sample was calcined under $500^{\circ} \mathrm{C}$ for $5 \mathrm{~h}$ to remove template.

\section{Characterization}

$\mathrm{N}_{2}$ adsorption-desorption isotherms of MS15-as and MS15-c were detected by using a Micromeritics ASAP 2050 volumetric adsorption analyzer at $-196^{\circ} \mathrm{C}$, and around $80-100 \mathrm{mg}$ of the composites were treated at $120^{\circ} \mathrm{C}$ for $3 \mathrm{~h}$ prior to test. The Brunauer-Emmett-Teller (BET) specific surface area was calculated by using adsorption data in the relative pressure between 0.04 and 0.2 , and the pore size distribution curves were obtained from the adsorption branch of the isotherm using the Barrett Joyner Halenda (BJH) algorithm. The scanning electron microscopy (SEM) images of MS15-as and MS15-c were obtained by using a Hitachi S4800 FE-SEM system with $10 \mathrm{kV}$ accelerating voltage and $10 \mathrm{~mA}$ of beam current. TEM images were obtained on a JEM-2100 electron microscope operating at $200 \mathrm{kV}$.

\section{Isolation and culture of CSCS}

C-kit-positive CSCs were isolated and obtained from the hearts of two-month-old wild-type male C57BL/6 mice (Yangzhou Laboratory Animal Center) according to methods previously described by our team [25-27]. A layer of fibroblast-like cells migrated from the adherent myocardial tissue after the CSCs were cultured almost for 10 days, which was cultured in complete explant medium (CEM: 78\% IMDM [Gibco, USA] mixture containing 20\% fetal calf serum [Gibco, USA], 2 mmol/l L-glutamine [Gibco, USA], $100 \mathrm{U} / \mathrm{ml}$ penicillin G [Gibco, USA], and $100 \mathrm{mg} / \mathrm{ml}$ streptomycin [Gibco, USA])). Some small, round, phase-bright cells were migrated from these fibroblast-like cells and then were collected using the digestion enzyme Accutase. Isolating enriched c-kit-positive cells using c-kit magnetic-activated cell sorting (MACS) magnetic beads (Miltenyi Biotec Inc.GER) following the manufacturer's instructions [28-30]. These separated cells were seeded at a concentration of $2 \times 10^{4}$ cells $/ \mathrm{ml}$ on poly-D-lysine-coated (Sigma, USA) dishes in cardiosphere growth medium (CGM: 65\% DMEM- F12 [Gibco, USA] mixture containing 10\% fetal calf serum [Gibco, USA], $2 \mathrm{mmol} / \mathrm{l} \mathrm{L-glutamine} \mathrm{[Gibco,} \mathrm{USA],} 0.1 \mathrm{mmol} / \mathrm{l}$ 2-mercaptoethanol [Sigma, USA], 2\% B27 [Gibco, USA], $5 \mathrm{ng} / \mathrm{ml}$ basic fibroblast growth factor (bFGF) [R\&D, USA], $10 \mathrm{ng} / \mathrm{ml}$ epidermal growth factor (EGF) [Peprotech, USA], $40 \mathrm{nmol} / \mathrm{l}$ cardiotrophin-1 [Peprotech, USA], $1 \mathrm{unit} / \mathrm{ml}$ thrombin [Sigma, USA], $100 \mathrm{U} / \mathrm{ml}$ penicillin G [Gibco, USA], and $100 \mathrm{mg} / \mathrm{ml}$ streptomycin [Gibco, USA]). 


\section{Cellular Physiology Cell Physiol Biochem 2018;49:2358-2370 \\ \begin{tabular}{ll|l} 
and Biochemistry Published onIIne: 28 September 2018 & $\begin{array}{l}\text { (c) } 2018 \text { The Author(s). Published by S. Karger AG, Basel } \\
\text { www.karger.com/cpb }\end{array}$ \\
\hline
\end{tabular}}

Sun et al.: 3D Mesoporous Scaffolds Sustained Release IGF-1

\section{Cell proliferation and morphology assays}

CSCs were cultured as the following procedure: 3D cell scaffolds MS15-c and 2D planar glass slice (with the simi lar concentration of IGF-1 with that released from MS15-c sample) were cultured with CSCs for 48 $\mathrm{h}$ at $37^{\circ} \mathrm{C}$ in a humidified atmosphere containing $5 \% \mathrm{CO}_{2}$. Then the cells were stained with DAPI to see cell adhesion behavior by using fluorescence microscopy. Meanwhile, the adhered cells were washed by PBS and immobilized by glutaraldehyde solution (2.0\%). The samples (MS15-c and 2D planar glass slice with adhered CSCs) were sputter-coated with gold and characterized by SEM.

\section{Characterization of CSCS}

Flow cytometric analysis was performed to phenotypically analyze the stem cells were isolated from the expanded cells using MACS as described above. The CSCs were isolated by enzymatic digestion using Accutase(which did not affect surface markers of cells), washed in phosphate-buffered saline (PBS) and blocked with 3\% fetal bovine serum for 15 min for flow cytometric analysis. A non-specific mouse IgG1 antibody (BD Biosciences, USA) was used as a control and the CSCs were labeled with FITC-conjugated rat anti-mouse c-kit (BD Biosciences, USA) for $30 \mathrm{~min}$ at $4^{\circ} \mathrm{C}$ in the dark. Subsequently, cells were washed twice with PBS solution and then re-suspended in buffer. Data were obtained with a FACS Calibur flow cytometer (BD Biosciences, USA) and analyzed by WinMDI software.

\section{Assessment of CSC migration}

To analyzed bioactivity of the scaffold released IGF-1, the c-kit-positive CSCs were washed with serumfree growth media and then were plated in the upper chambers of Transwell plates ( $8.0 \mu \mathrm{m}$ pore size) (Millipore, Billerica) at a concentration of $1 \times 10^{5}$ cells/well in $100 \mu \mathrm{l}$ of medium. Migration to the lower chamber, which was filled with $1 \mathrm{ml}$ of medium, was induced by the growth media supplemented with $2 \%$ serum (Negative Control) or with sample scaffold or with pooled IGF-1 sample scaffold release media $(100 \mathrm{ng} / \mathrm{mL})$ or with IGF-1(100ng/mL)(Positive Control) to the cells. After 48 - hours of incubation at $37^{\circ} \mathrm{C}$ in $5 \% \mathrm{CO}_{2}$, the cells were fixed with $4 \%$ paraformaldehyde and stained with $0.1 \%$ crystal violet to determine the number of migrated cells at the bottom side of the filter. The migrated cells were photographed using a phase contrast microscope, and the number of migrated cells was manually counted in three random fields per filter.

\section{Assessment of CSC proliferation}

CSC proliferation was measured in order to assess the bioactivity of the scaffold released IGF-1. C-kitpositive CSCs were cultured as described before. Cells were seeded in 24-well plates with 2D planar glass slice as negative control, with IGF-1 $(100 \mathrm{ng} / \mathrm{mL})$ as positive control, with sample scaffold and with pooled IGF-1 sample scaffold release media ( $100 \mathrm{ng} / \mathrm{mL})$ for $24 \mathrm{~h}$ at a concentration of $3 \times 10^{4}$ cells/well. Culture medium was then replaced with no serum medium starved for $12 \mathrm{~h}$ and then treated with CGM for 72 h. Double-stranded DNA (dsDNA) levels were measured according to the manufacturer's protocol. The QuantiT PicoGreen dsDNA assay (Invitrogen,USA).The cells were homogenised in the buffer mixed with 500 $\mu \mathrm{L} 0.2 \mathrm{M} \mathrm{NaHCO}_{3}$ and 1\% Triton-X lysis. To analysis Lysates, three freeze-thaw cycles prior were underwent and keep it at $-80{ }^{\circ} \mathrm{C}$ when available.

\section{5-Bromo-2'-deoxyuridine (BrdU) incorporation assay}

To assess CSC proliferation, a 5-bromo-2'-deoxyuridine (BrdU) incorporation assay was perfomed with a BrdU incorporation assay kit (Roche, USA). The cells were seeded with or without scaffold or IGF-1 in 96well microtiter plates at a density of $2 \times 10^{3}$ cells. According to manuscript, after $72 \mathrm{~h}$, added BrdU-labeling solution to the cells. After DNA denaturation, put peroxidase-labeled anti-BrdU monoclonal antibody to the cells and the samples were incubated at room temperature for $90 \mathrm{~min}$. The BrdU-antibody complexes were detected by a luminometer.

\section{Induction of MI Models}

Adult male C57BL / 6 mice (weight 22-25g) were deeply anesthetized with 1\% pentobarbital sodium $(40 \mathrm{mg} / \mathrm{kg})$.The mice head and limbs were fixed, cut the 4 th intercostal space on the left chest wall, separated into layers into the chest .Mechanically ventilated with a rodent respirator. The chest cavity was opened with a left thoracotomy to expose the heart, so that the left atrial appendage $2.0 \mathrm{~mm}$ could be visualized 


\section{Cellular Physiology Cell Physiol Biochem 2018;49:2358-2370

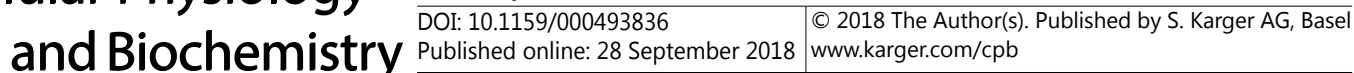

and be ligated with an 8-0 silk suture. Complete occlusion of the vessel was confirmed by the presence of myocardial bleaching.

Intra-myocardial Injection of CSCs and scaffolds with IGF-1

After ischemia-reperfusion at 28 days, MI Models mice underwent intra-myocardial injection of PBS, CSC, scaffold + CSC, CSC +fresh IGF-1,CSC+scaffold +IGF-1 ( $\mathrm{n}=5$ for each group). An insulin syringe was inserted into the myocardium. Before injection, cells were washed and re-suspended in PBS. For injections of CSCs alone or combination, 1 million CSCs were suspended in $0.3 \mathrm{~mL}$ PBS; All cells and combinations injections were divided into 3 equal-volume aliquots and injected with an insulin syringe.

\section{Echocardiographic Study}

All model mice underwent baseline echocardiography 4 weeks after ischemia-reperfusion and 4 weeks after CSC and combinations injection. Those animals underwent anesthesia method (1\% pentobarbital sodium, $40 \mathrm{mg} / \mathrm{kg}$ ) and shaved the chest. Placed in supine position and the transducer was placed directly on the shaved chest wall. Images were obtained from the left parasternal short-axis views of the left ventricle at the level of the papillary muscles to define cardiac function.

\section{Statistical analysis}

Data analysis was performed using SPSS (v 11.5, SPSS Inc.). The results were presented as the mean \pm standard deviation (SD), A minimum of $\mathrm{n}=3$ independent experiments unless otherwise stated. Statistical analysis of the differences between two groups was performed using Student's two-tailed t-test. Statistical significance was defined as $\mathrm{p}<0.05$.

\section{Results}

\section{Characterization of MS15-as and MS15-c samples}

Generally, the XRD patterns of a hexagonal mesoporous structure with high quality possess four peaks $(100,110,200$, and 210 reflection lines) [31, 32]. A low-angle XRD pattern of MS15-c is displayed in Fig. 2, showing three obvious peaks in the spectra. One peak located at around $1^{\circ}$ can be ascribed to the (100) diffraction of SBA-15. Two other wellresolved peaks, located at approximately $1.5^{\circ}$ and $1.7^{\circ}$, can be indexed as (110) and (200) diffractions illustrating the ordered mesoporous structure of the samples with p6mm hexagonal symmetry.

The 3D network morphology and ordered mesoporous structure were verified by SEM and TEM images of the MS15-c sample (Fig. 3). In the SEM images, a regular 3D network morphology was clearly observed in MS15-c, and numerous macropores with diameters of approximately $3 \mu \mathrm{m}$ were evenly distributed throughout the sample. Additionally, the TEM image verified that the MS15-c sample possessed ordered cylindrical channels, consistent with the XRD spectra (Fig. 2), which indicated the successful construction of a hierarchical pore structure (macropores and mesopores) in the MS15-c sample that could improve the

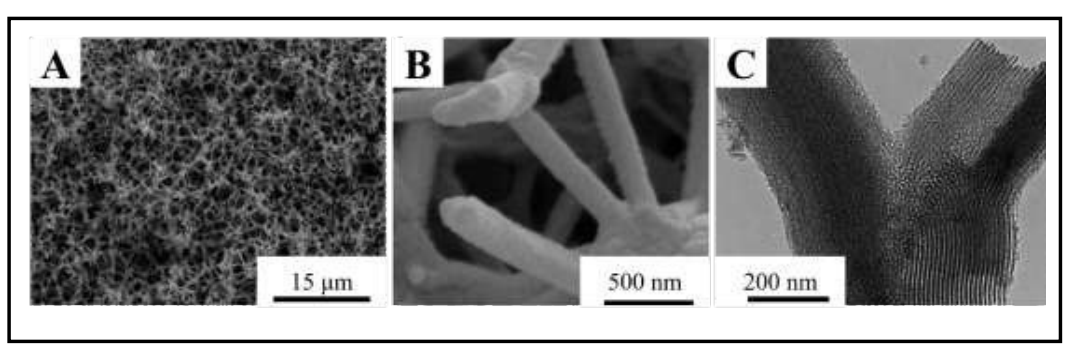

Fig. 3. SEM images of (A, B) MS15-c, and (C) TEM images of MS15-c.

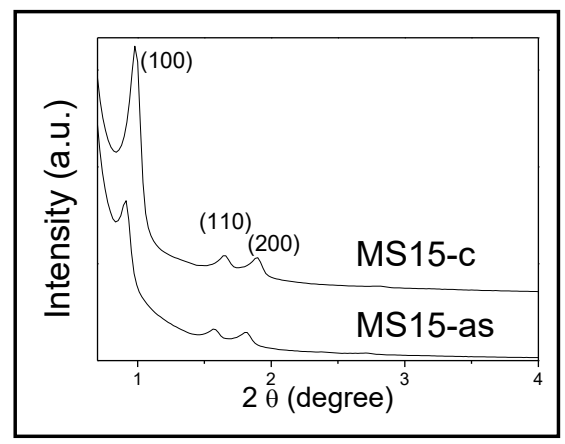

Fig. 2. XRD patterns of MS15-c. 
Fig. 4. Nitrogen adsorption/ desorption isotherms (a) and pore size distributions (b) of the samples. The isotherms for $\mathrm{Ti} / \mathrm{V}$ are offset vertically by $-30 \mathrm{~cm}^{3} \mathrm{~g}^{-1}$ ( at STP).

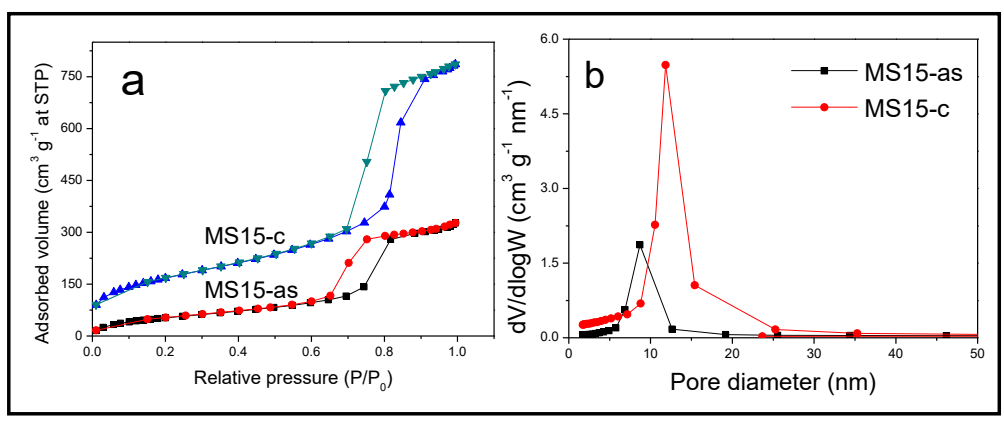

Fig. 5. (A) Adsorption amount of IGF-1 by different samples, and (B) Adsorption efficiency of IGF-1 by different samples.

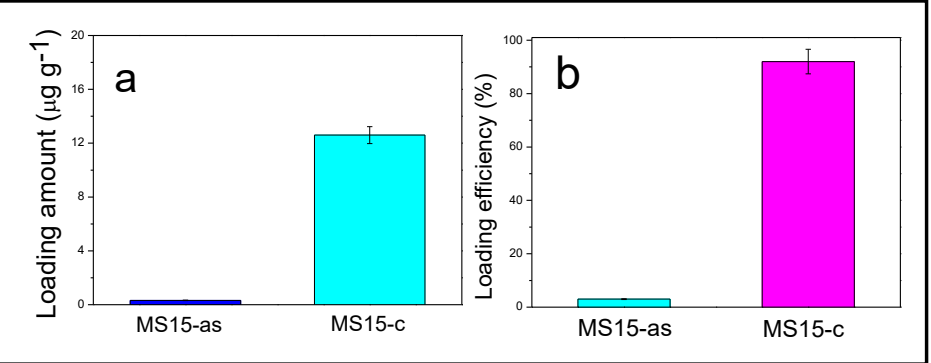

drug loading and release processes.

$\mathrm{N}_{2}$ adsorption-desorption isotherms under $-196^{\circ} \mathrm{C}$ were detected for the study of the specific area, pore volume, and pore size distribution of MS15-as and MS15-c samples. Typical type IV Table 1. Textural properties of the samples isotherms with sharp capillary condensation at

\begin{tabular}{lcccc}
\hline Samples & $\begin{array}{c}\mathrm{S}_{\mathrm{BET}} \\
\left(\mathrm{m}^{2} \mathrm{~g}^{-1}\right)\end{array}$ & $\begin{array}{c}\mathrm{S}_{\text {micro }} \\
\left(\mathrm{m}^{2} \mathrm{~g}-1\right)\end{array}$ & $\begin{array}{c}\mathrm{Vp} \\
\left(\mathrm{m}^{3} \mathrm{~g}-1\right)\end{array}$ & $\begin{array}{c}\mathrm{D} \\
(\mathrm{nm})\end{array}$ \\
\hline MS15-as & 207 & 0 & 0.49 & 9.0 \\
MS15-c & 612 & 40 & 1.2 & 12.1 \\
\hline
\end{tabular}
high relative pressure were observed (Fig. 4a). Additionally, H1-type hysteresis loops were observed, indicating uniform mesopores in the samples. The textural properties of MS15-as and MS15-c are summarized in Table 1. The BET surface area increased from $207 \mathrm{~m}^{2} \mathrm{~g}^{-1}$ to $612 \mathrm{~m}^{2} \mathrm{~g}^{-1}$ after calcination of the template, and the pore size of the samples increased from $9.0 \mathrm{~nm}$ to $12.1 \mathrm{~nm}$ (Fig. $4 \mathrm{~b}$ ).

\section{IGF-1 adsorption and release performance}

The adsorption of IGF-1 by MS15-c and MS15-as composites is summarized in Fig. 5. The MS15-c sample adsorbed approximately $12 \mu \mathrm{g} \mathrm{g}^{-1}$ (adsorption ratio was as high as $92 \%$ ), which was 37 times more than that of the MS15-as sample (the adsorption ratio was approximately 3\%), thus implying that the mesoporous structure made a positive contribution to the sample (a MS15-as sample without the template removed can barely adsorb IGF-1).

Fig. 6 shows the release of IGF-1 on MS15-as and MS15-c. As expected, the MS15-as sample, which adsorbed minimal IGF-1, released only approximately $100 \mathrm{ng} \mathrm{g}^{-1}$ for around $10 \mathrm{~h}$ before the release process stopped. In contrast, MS15-c, which contained a much greater amount of IGF-1, exhibited a higher concentration plateau, and the release lasted for at least $250 \mathrm{~h}$. Fig. 6 a shows that an initial release burst occurred in the first $10 \mathrm{~h}$ on MS15-c; this was attributed to the desorption of IGF-1 located on the macropores in the sample. The release rate slowed down over the following $50 \mathrm{~h}$. IGF-1 release in the final stage was relatively slow but still lasted for $250 \mathrm{~h}$. To further investigate the release mechanism of IGF1 on MS15-c, two release models (the Higuchi [1961] model $\left[M_{t} / M_{\infty}=a \times t^{1 / 2}\right]$ and the Peppas [1987] model $\left[M_{t} / M_{\infty}=a \times t^{b}\right]$ ) were applied [33]. In these models, $a$ is a kinetic constant, $b$ is an exponent representing the diffusion mechanism, and $M_{t}$ and $M_{\infty}$ are the cumulative amount of IGF-1 released at time $t$ and infinite time, respectively. The Peppas model equals the Higuchi model when the value of $b$ equals 0.5. If the logarithm of the Peppas equation is taken, the following formula can be obtained: 
Fig. 6. (a) Release profiles of different samples, and (b) Release data fits to Peppas model for MS15-c.

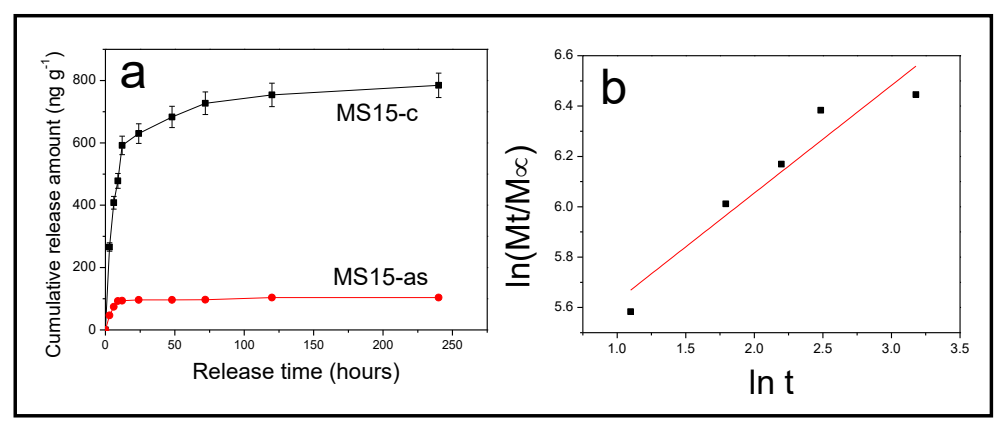

Fig. 7. (A) Characterization of cultured CSCs. (i) $\mathrm{CSC}_{\mathrm{s}}$ were obtained from adult C57BL/6 mouse hearts was cut into $1-2 \mathrm{~mm}^{3}$ pieces. (ii) A layer of fibroblast cells emerged from adherent myocardial tissues after 7 days. Scale bar: $50 \mu \mathrm{m}$. (iii) Some small, round, phase-bright migrated from the cardiac explants, aggregated and proliferated over the fibroblast layer after 14 days of culture. Scale bar: $50 \mu \mathrm{m}$. (B) Representative flow cytometric analyses of CSCs for positive expression of the cell surface markers c-kit is $95.30 \%$ (negative control is $0.78 \%$ ).

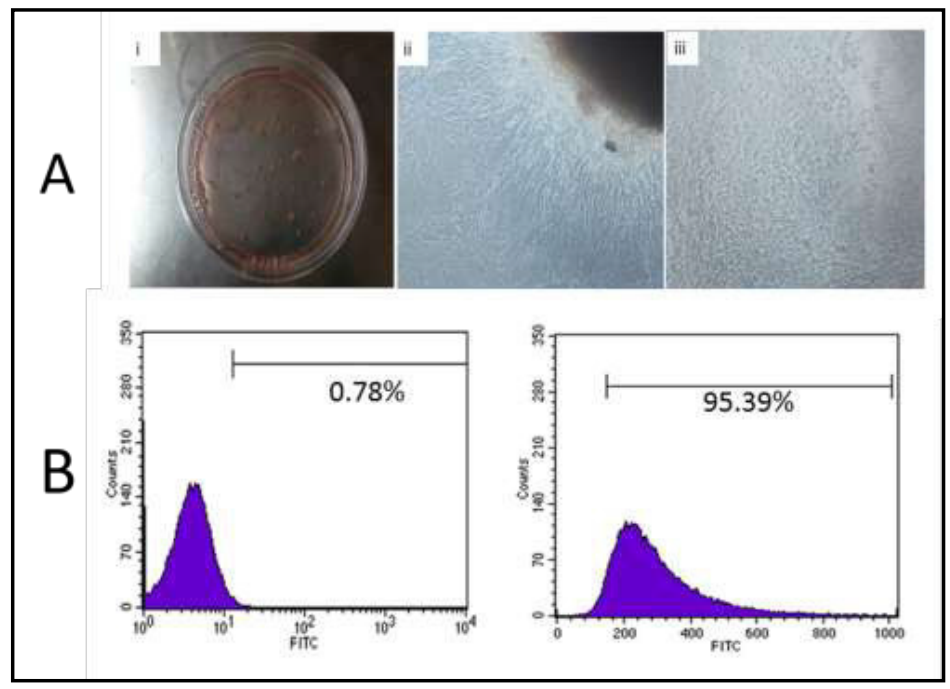

$\ln M_{t} / M_{\infty}=\ln a+b \ln t$.

By plotting $\ln M_{t} / M_{\infty}$ against $\ln \mathrm{t}$, a line was obtained with the slope and intercept as $b$ and $\ln a$, respectively (Fig. 6b). In Fig. $6 \mathrm{~b}$, the value of $b$ is 0.43 , indicating that the release mechanism of IGF-1 from MS15-c was more applicable to the Higuchi model, which implied that the MS15-c sample possessed unique pores [34].

\section{Isolation and expansion of murine c-kit-positive cardiac stem cells}

Isolated myocardial tissue from adult C57BL/6 mouse hearts was cut into 1-2 $\mathrm{mm}^{3}$ pieces (Fig. 7A i), and a layer of fibroblast cells emerged from adherent myocardial tissues (Fig. 7A ii) migrating from fibroblast cells and myocardial tissues as numerous small, round, phase-bright cells after approximately 10 days of culture (Fig. 7A iii). Images of CSCs were obtained using an inverted phase-contrast microscope. CSCs were then separated by c-kit magnetic beads using magnetic-activated cell sorting and cultured in cardiosphere growing medium (CGM). These $c$-kit-positive CSCs showed clone-like proliferation after magneticactivated cell sorting for 7 days. Phenotypic analysis of c-kit expression $(95.39 \% \pm 7.14 \%)$ was identified by flow cytometric analysis (Fig. 7B).

\section{Cell proliferation and morphology assays}

To determine whether the 3D cell scaffolds and the released IGF-1 could promote the adhesion and growth of CSCs, CSCs cultured with MS15-c for $48 \mathrm{~h}$ were stained with DAPI and the cell adhesion behavior was observed using fluorescence microscopy (Fig. 8). As a comparison, a two-dimensional (2D) planar glass slice was used as a support to culture cells with a similar concentration of IGF-1. Much higher densities of CSCs cultured on MS15-c were seen, and fewer cells were displayed on the surface of the 2D planar glass, indicating the promoting effect of 3D cell scaffolds on the proliferation of cells. Fig. 8C and Fig. 7D show 


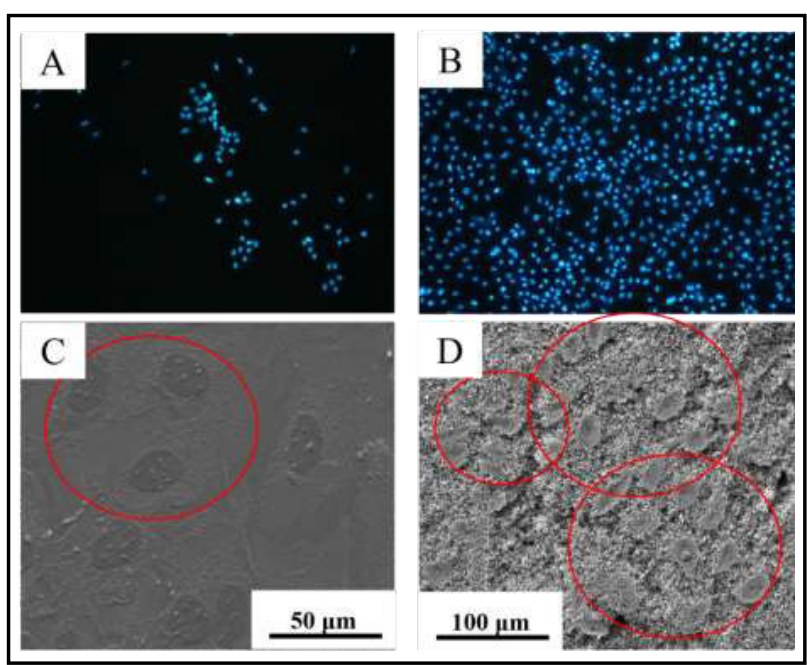

Fig. 8. Fluorescence micrographs of cell adhesion (CSCs) on the (A) 2D plane and (B) 3D MS15-c after $48 \mathrm{~h}$ incubation. The magnification is $100 \times$, and SEM images of adhered cells on (C) 2D plane and (D) 3D MS15-c for $48 \mathrm{~h}$.

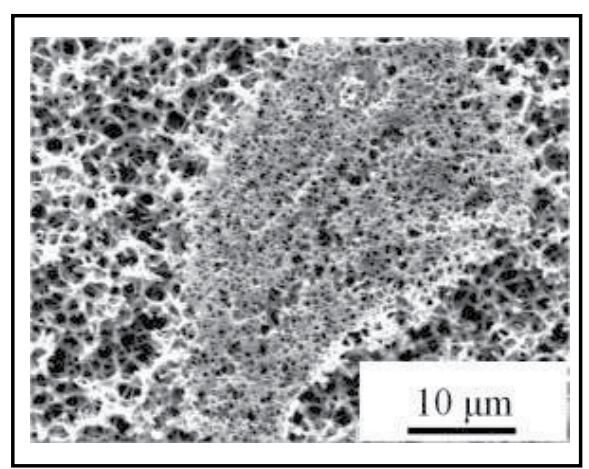

Fig. 9. SEM image of the cell adhered on the scaffolds of MS15-c under high magnification.

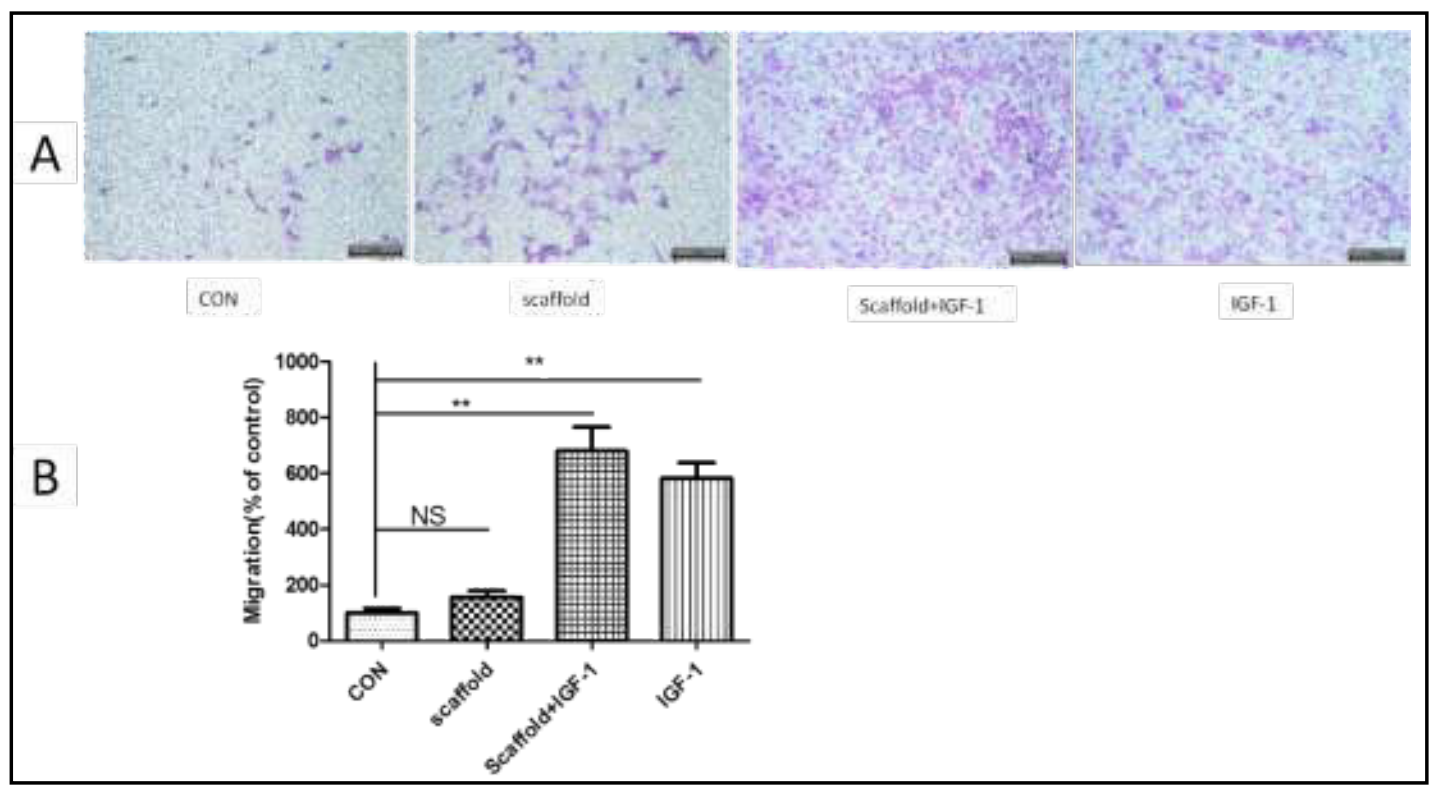

Fig. 10. C-kit-positive CSCs were respectively treated with in $2 \%$ serum media (control), scaffold only, and IGF-1 scaffold release media (100 ng/mL)and supplemented with fresh IGF-1 (100 ng/mL) as positive control. cells were migrated to the basolateral side of the inserts. After $48 \mathrm{~h}$ incubation, Fixed with $4 \%$ paraformaldehyde and stained with $0.1 \%$ crystal violet. Representative migrated c-kit-positive CSCs are shown in different groups as $158 \pm 49.2 \%$ ( $p>0.05$ ), 680 $\pm 191.3 \%$ (** $p<0.01$ ), $582 \pm 124.4 \%$ (** $p<0.01$ ). The data were obtained from 5 independent experiments and are expressed as the mean \pm SD. $n=5 . * * p<0.01$ vs CON.

the SEM images of CSC proliferation on 2D planar glass and MS15-c, respectively. The cell densities on MS15-c, with drug release ability and a 3D structure, were much higher than those on 2D planar glass. A high-powered SEM image was added to the revised manuscript (Fig. 9). The adhered cells were fixed with paraformaldehyde and then freeze-dried to remove the water. The SEM images of cells adhered to the scaffolds of MS15-c under high magnification (Fig. 9) displayed multiple contact points in the absence of water. 
Analysis of the migration of IGF-1 scaffold on c-kit-positive CSCs

To assess the migration behavior of IGF-1 released from the scaffold, c-kit-positive cardiac stem cells were seeded in transwell insertions in a 12-well plate. C-kit-positive CSCs were starved in serum free media for $3 \mathrm{~h}$ and treated with $2 \%$ serum media (control), scaffold only, and IGF-1 scaffold release media $(100 \mathrm{ng} / \mathrm{mL}$ ) supplemented with fresh IGF-1 (100 ng/ $\mathrm{mL}$ ) as the positive control. After $48 \mathrm{~h}$ of incubation, cells had migrated to the basolateral side of the inserts and were stained with $0.1 \%$ crystal violet. Cell migration was quantified by cell counts in 5 random fields (Fig. 10A). As shown in Fig. 10B, c-kit-positive CSC treatment with scaffold released IGF-I stimulated cell migration was approximately $680 \% \pm 191.3 \%$ (P $<0.001)$, while the positive control group was $582 \% \pm 124.4 \%(\mathrm{P}<0.001)$, and the scaffold group was $158 \% \pm 49.2 \%$. C-kit-positive CSCs exposed to a scaffold with IGF-1 showed a higher level of migration through the membrane compared to fresh IGF-1.

\section{Analysis of the proliferation of IGF-1 scaffold on c-kit-positive CSCs}

To assess the proliferation performance of IGF-1 released from the scaffold, c-kitpositive CSCs were allocated to different treatment groups as follows: incubation with $2 \%$ serum media (control), scaffold with $2 \%$ serum media only, CGM, scaffold with CGM, and IGF-1 scaffold release media (100 ng/mL) supplemented with fresh IGF-1 (100 ng/mL) as the positive control. C-kitpositive CSCs were seeded without serum and starved for $24 \mathrm{~h}$ prior to experiments. Cell growth was assessed quantitatively via a PicoGreen doublestranded (ds) DNA assay after $72 \mathrm{~h}$ of incubation. As shown in Fig. 11, the DNA content in the four groups increased more during cell culture than that of the control group $(\mathrm{P}<$ 0.01 ). The group with IGF1 scaffold release media displayed an even higher level of c-kit-positive CSC growth compared with the group supplemented with fresh IGF-1. Additionally, the scaffold with the CGM group showed a higher level of growth than that of the CGM group; however, there was no statistically significant difference $(\mathrm{P}>$ 0.05). The increase in DNA indicated improved cell proliferation on scaffolds and scaffold release of IGF1 in vitro compared with these parameters in 2D plane and fresh IGF-1.

Fig. 11. C-kit-positive CSCs were respectively treated with in $2 \%$ serum media (control), scaffold with $2 \%$ serum media only, CGM, scaffold with CGM ,IGF-1 scaffold release media (100 $\mathrm{ng} / \mathrm{mL}$ )and supplemented with fresh IGF-1 (100 ng/ $\mathrm{mL}$ ) as positive control. DS DNA levels were assessed by picogreen assay. DNA concentration in each group previously described as $178 \pm 44.38 \mathrm{ng} / \mathrm{ml}, 181 \pm 67.61 \mathrm{ng} / \mathrm{ml}, 325.4 \pm 82.7 \mathrm{ng} / \mathrm{ml}, 375.8 \pm 124.6 \mathrm{ng} /$ $\mathrm{ml}, 577.8 \pm 160.4 \mathrm{ng} / \mathrm{ml}, 458 \pm 97.57 \mathrm{ng} / \mathrm{ml}$. The data were obtained from 5 independent experiments and are expressed as the mean \pm SD. $n=5$. $* * \mathrm{p}<0.01$ vs con.

Fig. 12. C-kit-positive CSCs were respectively treated with CGM, scaffold with CGM, IGF-1 scaffold release media (100 ng/ mL)and supplemented with fresh IGF-1 (100 ng/ $\mathrm{mL}$ ) as positive control. Cell proliferation was quantified using a BrdU method. Proliferation in the quiescent state was deemed to be $100 \%$. The data were

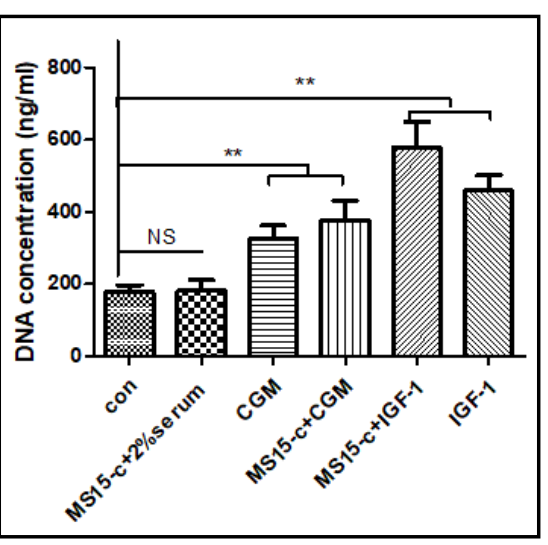
obtained from 3 independent experiments and are expressed as the mean \pm SD. $n=5$. ${ }^{*} \mathrm{p}<0.05$ group scaffold $+\mathrm{IGF}-1$ vs con. ${ }^{*} \mathrm{p}<0.05$ group scaffold+IGF-1 vs fresh IGF-1. 


\section{Cellular Physiology Cell Physiol Biochem 2018;49:2358-2370 and Biochemistry \begin{tabular}{c|c|c|c|} 
DOI: 10.1159/000493836 & $\begin{array}{l}\text { O } 2018 \text { The Author(s). Published by S. Karger AG, Basel } \\
\text { www.karger.com/cpb }\end{array}$
\end{tabular}

Fig. 13. C-kit-positive CSCs were respectively treated with fresh IGF-1 (100 ng/mL) and IGF-1 scaffold release media $(100 \mathrm{ng} / \mathrm{mL})$. proliferation was quantified using a BrdU method. Proliferation in the fresh IGF-1 state was deemed to be 1 . all three time point show IGF-1 scaffold promote cell growth than fresh IGF-1 release.
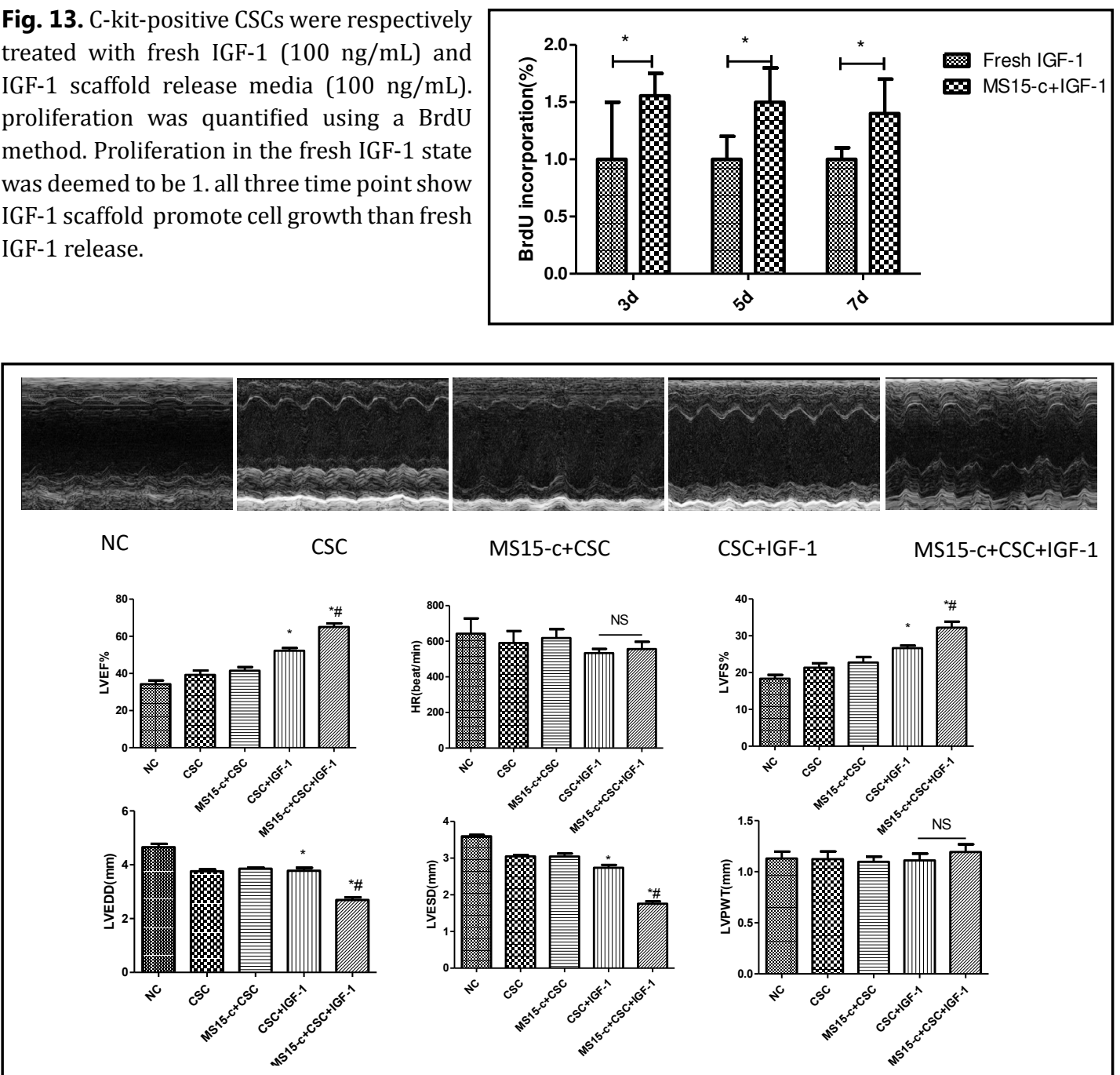

Fig. 14. Echocardiogram of mice heart in different groups at 28 days after MI. NC as negative control group. b Index of LVEF,LVFS, HR, LVESD,LVEDD, and LVPW in different groups $\left({ }^{*} \mathrm{P}<0.05\right.$ VS NC, \#P<0.05 VS CSC+IGF-1).

\section{Discussion}

To further assess cell proliferation, we used a BRDU assay in this work [35]. It is evident that the number of c-kit-positive CSCs cultured with scaffold MS15-c was approximately $21.7 \%$ higher than that of the control sample (Fig. 12), while that of c-kit-positive CSCs cultured with scaffold MS15-c with IGF-1 was approximately $108 \%$ higher than that of the control and $80 \%$ higher than that of cells cultured with free IGF-1. These results indicated that scaffolds with released IGF-I can effectively promote cell proliferation.

A high concentration of growth factors may be cytotoxic to cell growth [36-38]. Thus, the sustained release of IGF-1 is of great significance to facilitate the proliferation of cells. Additionally, loading IGF-1 to the MS15-c scaffold can potentially protect IGF-1 from being inactivated.

IGF-1 can promote the proliferation and migration of many kinds of cells [39-41]. Fig. 9B and Fig. 10 in our manuscript demonstrated that the scaffold with released IGF-1 had a DNA concentration of approximately $400 \mathrm{ng} / \mathrm{mL}$, while that of fresh IGF-1 was approximately 700 $\mathrm{ng} / \mathrm{mL}$. In addition, the scaffold releasing IGF-1 showed a stronger biological effect than that of fresh IGF-1. We additionally designed an experiment to detect cell proliferation at days 5 
and 7 with scaffolds plus IGF-1 or fresh IGF-1. The results demonstrated that the sustained release of IGF-1 promotes significantly greater cell proliferation than fresh IGF-1 (Fig. 13). The DNA concentration in MS15-C released from the IGF-1 group was almost 2-fold higher than that of the fresh IGF-1 group at 7 days.

Our ultimate research goal is to improve the survival rates and heart function among patients with cardiovascular diseases. The transplantation of CSC is one of the strategies used to try and achieve that goal. To improve the survival of CSCs, our device containing growth factors is designed to prolong the half-life of each growth factor and enhance the physiological role of IGF-1. There are many causes of the low survival rates of CSCs after transplantation, including microenvironmental changes in the body, lack of blood supply, or lack of growth factors. One of the factors we incorporated in modifying the design of this device was to supplement the lack of growth factors and provide relatively stable cell growth in vivo. Our in vitro experiments proved that we were successful. Currently, we are designing experiments to enable more diverse growth factors to be loaded onto our scaffolds to promote the growth of both stem cells and neovascularization. We completed the experimental construction of a myocardial infarction model in mice treated with cardiac stem cells, namely, MS15-C, MS15-C + CSC, FRESH IGF-1 + CSC, and MS15-C + IGF-1 + CSC over 4 weeks. Echocardiograms of mouse hearts were used to measure heart function. The results showed that MS15-C controlled-release IGF-1 and CSCs improved the EF by $20 \%$ compared with NC and CSCs only (Fig. 14).

\section{Conclusion}

In conclusion, this work successfully demonstrated an effective strategy for the construction of MS15-c cell scaffolds with hierarchical macro-mesoporous structures. The macro-mesoporous structures gave cell scaffolds the ability to release a growth factor to facilitate cell growth, while the scaffold structure promoted cell proliferation. The adsorption of IGF-1 by MS15-c was approximately $12 \mu \mathrm{g} \mathrm{g}^{-1}$ (the adsorption ratio was as high as $92 \%$ ). The delivery of IGF-1 by MS15-c was achieved, and the adsorption was greatly enhanced by macropores and mesopores combined. The release of IGF-1 can be sustained for at least $250 \mathrm{~h}$. Additionally, the 3D microenvironment constructed within MS15-c can mimic the 3D growth environment required by cells and accelerate the rate of c-kit-positive CSC proliferation and migration. The cellular assays proved that the bioactivity of IGF-1 was maintained during the release process. The results also demonstrated that the number of c-kit-positive CSCs cultured with scaffold MS15-c and IGF-1 was approximately 108\% higher than that of the control sample, which was $80 \%$ that of cells cultured with free IGF-1. MI models of mice were constructed, and the group of scaffolds with released IGF-1 plus CSC improved heart function most effectively. These results implied that this kind of scaffold, and its capacity to release IGF-1 in a sustained manner, could be improved for use in vivo.

\section{Acknowledgements}

The work was financially supported by the National Natural Science Foundation of China (No. 81400219, 81400225 and 81500204) and Natural Science Foundation of Jiangsu Province (No. BK20150648), Jiangsu Provincial Medical Youth Talent(QNRC2016815).

\section{Disclosure Statement}

The authors declare that no non-financial conflicts and financial conflicts of interest exist for any of the authors. 


\section{Cellular Physiology Cell Physiol Biochem 2018;49:2358-2370 \begin{tabular}{l|l|l} 
and BOI: 10.1159/000493836 & $\begin{array}{l}\text { (O) 2018 The Author(s). Published by S. Karger AG, Basel } \\
\text { www.karger.com/cpb }\end{array}$ \\
\hline
\end{tabular} \\ Sun et al.: 3D Mesoporous Scaffolds Sustained Release IGF-1}

\section{References}

1 Mozaffarian D, Benjamin EJ, Go AS, Arnett DK, Blaha MJ, Cushman M, Das SR, de Ferranti S, Despres JP, Fullerton HJ and others. Heart Disease and Stroke Statistics-2016 Update: A Report From the American Heart Association. Circulation 2016;133:e38-360..

-2 Mehta A, Shim W. Cardiac Stem Cell Therapy: Stemness or Commitment? Cell Transplant 2013;22:1-14.

- 3 Messina E, De Angelis L, Frati G, Morrone S, Chimenti S, Fiordaliso F, Salio M, Battaglia M, Latronico MV, Coletta $\mathrm{M}$ and others. Isolation and expansion of adult cardiac stem cells from human and murine heart. Circ Res 2004;95:911-921.

-4 Leong YY, Ng WH, Ellison-Hughes GM, Tan JJ. Cardiac Stem Cells for Myocardial Regeneration: They Are Not Alone. Front Cardiovasc Med 2017;4:47.

- 5 Liu J, Wu P, Wang H, Wang Y, Du Y, Cheng W, Xu Z, Zhou N, Wang L, Yang Z. Necroptosis Induced by AdHGF Activates Endogenous C-Kit+ Cardiac Stem Cells and Promotes Cardiomyocyte Proliferation and Angiogenesis in the Infarcted Aged Heart. Cell Physiol Biochem 2016;40:847-860.

6 Hong KU, Guo Y, Li QH, Cao P, Al-Maqtari T, Vajravelu BN, Du J, Book MJ, Zhu X, Nong Y and others. c-kit+ Cardiac stem cells alleviate post-myocardial infarction left ventricular dysfunction despite poor engraftment and negligible retention in the recipient heart. PLoS One 2014;9:e96725.

7 Franco C, Bengtsson BA, Johannsson G. The GH/IGF-1 Axis in Obesity: Physiological and Pathological Aspects. Metab Syndr Relat Disord 2006;4:51-56.

8 Ma R, Wang L, Zhao B, Liu C, Liu H, Zhu R, Chen B, Li L, Zhao D, Mo F and others. Diabetes Perturbs Bone Microarchitecture and Bone Strength through Regulation of Sema3A/IGF-1/beta-Catenin in Rats. Cell Physiol Biochem 2017;41:55-66.

-9 Troncoso R, Ibarra C, Vicencio JM, Jaimovich E, Lavandero S. New insights into IGF-1 signaling in the heart. Trends Endocrin Met 2014;25:128-137.

$>10$ Ellison GM, Torella D, Dellegrottaglie S, Perez-Martinez C, Perez De Prado A, Vicinanza C, Purushothaman S, Galuppo V, Iaconetti C, Waring CD and others. Endogenous Cardiac Stem Cell Activation by Insulin-Like Growth Factor-1/Hepatocyte Growth Factor Intracoronary Injection Fosters Survival and Regeneration of the Infarcted Pig Heart. J Am Coll Cardiol 2011;58:977-986.

11 DiTizio V, Karlgard C, Lilge L, Khoury AE, Mittelman MW, DiCosmo F. Localized drug delivery using crosslinked gelatin gels containing liposomes: factors influencing liposome stability and drug release. J Biomed Mater Res 2000;51:96-106.

12 Hu M, Chen J, Li ZY, Au L, Hartland GV, Li X, Marquez M, Xia Y. Gold nanostructures: engineering their plasmonic properties for biomedical applications. Chem Soc Rev 2006;35:1084-94.

13 Hartmann L, Hafele S, Peschka-Suss R, Antonietti M, Borner HG. Tailor-made poly(amidoamine)s for controlled complexation and condensation of DNA. Chemistry 2008;14:2025-2033.

14 Klostranec JM, Chan WCW. Quantum Dots in Biological and Biomedical Research: Recent Progress and Present Challenges. Adv Mater 2006;18:1953-1964.

15 Wang Y, Zhao Q, Han N, Bai L, Li J, Liu J, Che E, Hu L, Zhang Q, Jiang T and others. Mesoporous silica nanoparticles in drug delivery and biomedical applications. Nanomedicine 2015;11:313-327.

-16 Tamanna T, Bulitta JB, Yu A. Controlling antibiotic release from mesoporous silica nano drug carriers via self-assembled polyelectrolyte coating. J Mater Sci Mater Med 2015;26:117.

-17 Wan M, Zhang J, Wang Q Zhan S, Chen X, Mao C, Liu Y, Shen J. In Situ Growth of Mesoporous Silica with Drugs on Titanium Surface and Its Biomedical Applications. ACS Appl Mater Interfaces 2017;9:1860918618.

-18 Chao J, Wang X, Zhang Y, Zhu T, Zhang W, Zhou Z, Yang J, Han B, Cheng Y, Tu X and others. Role of MCPIP1 in the Endothelial-Mesenchymal Transition Induced by Silica. Cell Physiol Biochem 2016;40:309-325.

19 Chen Y, Chen H, Shi J. In vivo bio-safety evaluations and diagnostic/therapeutic applications of chemically designed mesoporous silica nanoparticles. Adv Mater 2013;25:3144-76.

20 Lee JE, Lee N, Kim H, Kim J, Choi SH, Kim JH, Kim T, Song IC, Park SP, Moon WK and others. Uniform mesoporous dye-doped silica nanoparticles decorated with multiple magnetite nanocrystals for simultaneous enhanced magnetic resonance imaging, fluorescence imaging, and drug delivery. J Am Chem Soc 2010;132:552-557.

-21 Lee JE, Lee N, Kim T, Kim J, Hyeon T. Multifunctional mesoporous silica nanocomposite nanoparticles for theranostic applications. Acc Chem Res 2011;44:893-902. 


\section{Cellular Physiology Cell Physiol Biochem 2018;49:2358-2370 \begin{tabular}{l|l|l|l|}
\hline DOI: 10.1159/000493836 & $\begin{array}{l}\text { C) } 2018 \text { The Author(s). Published by S. Karger AG, Basel } \\
\text { www.karger.com/cpb }\end{array}$
\end{tabular}

22 Vallet-Regi M, Balas F, Arcos D. Mesoporous materials for drug delivery. Angew Chem Int Ed Engl 2007;46:7548-7558.

23 Li Z, Barnes JC, Bosoy A, Stoddart JF, Zink JI. Mesoporous silica nanoparticles in biomedical applications. Chem Soc Rev 2012;41:2590-2605.

24 Yang P, Gai S, Lin J. Functionalized mesoporous silica materials for controlled drug delivery. Chem Soc Rev 2012;41:3679-3698.

-25 Lutolf MP, Hubbell JA. Synthetic biomaterials as instructive extracellular microenvironments for morphogenesis in tissue engineering. Nat Biotechnol 2005;23:47-55.

-26 Yamada Y, Ueda M, Naiki T, Takahashi M, Hata K, Nagasaka T. Autogenous injectable bone for regeneration with mesenchymal stem cells and platelet-rich plasma: tissue-engineered bone regeneration. Tissue Eng 2004;10:955-964.

27 William Y, Nan D, Chun C, Eduardo S, David M: Mimicking nature by codelivery of stimulant and inhibitor to create temporally stable and spatially restricted angiogenic zones. Proc Natl Acad Sci U S A 2010;107:17933-17938.

28 Fengdi Y, Yuyu Y, Lijuan C, Yefei L, Zulong S, Genshan M: Hypoxic preconditioning improves survival of cardiac progenitor cells: Role of stromal cell derived factor-1alpha-CXCR4 axis. PLoS One 2012;7:e37948.

29 Rongfeng X, Yuning S, Zhongpu C, Yuyu Y, Genshan M: Hypoxic preconditioning inhibits hypoxia-induced apoptosis of cardiac progenitor cells via the PI3K/Akt-DNMT1-p53 pathway. Sci Rep 2016;6:30922.

-30 Zhongpu C, Xiaodong P, Yuyu Y, Fengdi Y, Long C, Rong H, Genshan M: Epigenetic regulation of cardiac progenitor cells marker c-kit by stromal cell derived factor-1alpha. PLoS One 2013;8:e69134.

31 Mimi W, Jiayuan Y, Yue Q Yu Z, Chenxi G, Qian H, Weigang L, Jianhua Z: Sustained release of heparin on enlarged-pore and functionalized MCM-41. ACS Appl Mater Interfaces 2012;4:4113-4122.

-32 Mimi W, Yanyan L, Tian Y, Tao Z ,Xiaodan S, Jianhua Z: In Situ Loading of Drugs into Mesoporous Silica SBA15. Chemistry 2016;22:6294-6301.

-33 Karewicz A, Zasada K, Szczubialka K, Zapotoczny S, Lach R, Nowakowska M. “Smart” alginatehydroxypropylcellulose microbeads for controlled release of heparin. Int J Pharm 2010;385:163-169.

-34 Li W, Huang SJ, Liu SB, Coppens MO. Influence of the Al source and synthesis of ordered Al-SBA-15 hexagonal particles with nanostairs and terraces. Langmuir 2005;21:2078-2085.

-35 Galand PE, Alonso-Saez L, Bertilsson S, Lovejoy C, Casamayor EO. Contrasting activity patterns determined by BrdU incorporation in bacterial ribotypes from the Arctic Ocean in winter. Front Microbiol 2013;4:118.

-36 Rogachefsky RA, Dean DD, Howell DS, Altman RD. Treatment of canine osteoarthritis with insulin-like growth factor-1 (IGF-1) and sodium pentosan polysulfate. Osteoarthr 1993;1:105-114.

37 Davis ME, Hsieh PC, Takahashi T, Song Q Zhang S, Kamm RD, Grodzinsky AJ, Anversa P, Lee RT. Local myocardial insulin-like growth factor 1 (IGF-1) delivery with biotinylated peptide nanofibers improves cell therapy for myocardial infarction. Proc Natl Acad Sci U S A 2006;103:8155-8160.

-38 Li Y, Li Y, Zhang J, Zheng C, Zhu H, Yu H, Fan L. Circulating Insulin-Like Growth Factor-1 Level and Ovarian Cancer Risk. Cell Physiol Biochem 2016;38:589-597.

39 Chen G, Fang T, Huang Z, Qi Y, Du S, Di T, Lei Z, Zhang X, Yan W. MicroRNA-133a Inhibits Osteosarcoma Cells Proliferation and Invasion via Targeting IGF-1R. Cell Physiol Biochem 2016;38:598-608.

-40 Ashpole NM, Sanders JE, Hodges EL, Yan H, Sonntag WE. Growth hormone, insulin-like growth factor-1 and the aging brain. Exp Gerontol 2015;68:76-81.

-41 Backeljauw PF, Miller BS, Dutailly P, Houchard A, Lawson E, Hale DE, Reiner B, Sperling MA. Recombinant human growth hormone plus recombinant human insulin-like growth factor-1 coadministration therapy in short children with low insulin-like growth factor- 1 and growth hormone sufficiency: results from a randomized, multicenter, open-label, parallel-group, active treatment-controlled trial. Horm Res Paediatr 2015;83:268-279. 